ON THE RELATIONS OF PHENOL AND META-CRESOL TO PROTEINS; A CONTRIBUTION TO OUR KNOWLEDGE OF THE MECHANISM OF DISINFECTION

\author{
By E. A. COOPER, B.Sc., Beit Memorial Fellow, formerly Jenner \\ Scholar, Lister Institute of Preventive Medicine.
}

(Received July 2nd, 1912)

\title{
CONTENTS
}

$\begin{array}{lllllllll}\text { Introduction and method of study } & \ldots & \ldots & \ldots & \ldots & \ldots & \ldots & \ldots & 362\end{array}$

I. The influence of concentration upon the distribution of phenol between water and proteins-
(a) Gelati
(b) Dissolved egg-albumen
(c) Heat-coagulated egg-albumen

..
(d) Heat-coagulated egg-globulin
(e) Casein

$$
\begin{array}{cccccc}
\ldots & \ldots & \ldots & \ldots & \ldots & 365 \\
\ldots & \ldots & \ldots & \ldots & \ldots & 368 \\
\ldots & \ldots & \ldots & \ldots & \ldots & 372 \\
\ldots & \ldots & \ldots & \ldots & \ldots & 373
\end{array}
$$$$
\ldots \quad \ldots \quad \ldots \quad \ldots \quad \ldots \quad 368
$$

II. The influence of temperature upon the distribution of phenol between water and proteins-

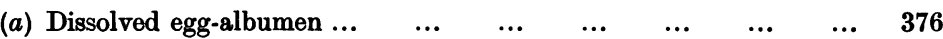

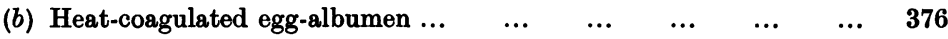

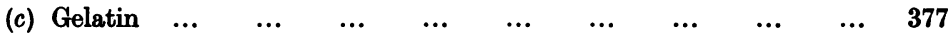

III. The influence of alcohol upon the distribution of phenol between water and $\begin{array}{lllllllll}\text { heat-coagulated egg-albumen } & \ldots & \ldots & \ldots & \ldots & \ldots & \ldots & \ldots & 377\end{array}$

IV. The influence of hydrochloric acid upon the distribution of phenol between $\begin{array}{lllllll}\text { water and heat-coagulated egg-albumen } & \ldots & \ldots & \ldots & \ldots & \ldots & 378\end{array}$

V. The influence of concentration upon the distribution of m-cresol between water and proteins-

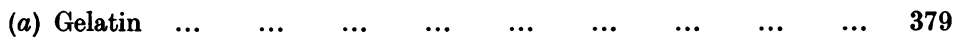

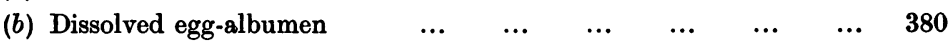

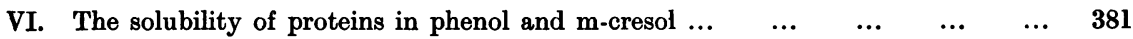

VII. The application of some of these facts to the theory of phenol disinfection $\quad \ldots \quad 382$

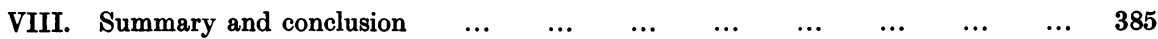

In the case of such substances as formaldehyde, halogens, mercuric chloride, oxidising agents, acids and alkalies, it is possible to understand why they should behave as disinfectants, as they all form chemical combinations with proteins. We have, however, very little knowledge of the relations of phenol and the cresols to proteins, so that it is at present not possible to understand the nature of the germicidal action of these common disinfectants. 
Reichel, ${ }^{1}$ in 1909, showed that heat-coagulated serum and egg-white absorbed phenol from its aqueous solution in an amount directly proportional to the concentration and that the process was reversible. He also showed that Bacillus pyocyaneus absorbed phenol, and that the addition of sodium chloride increased the uptake by both bacilli and heat coagula and also increased the bactericidal action of phenol.

Herzog and Betzel, ${ }^{2}$ in 1911, found that yeast reversibly absorbed phenol in an amount, which relatively decreased with rise in concentration. A rise in phenol concentration, on the other hand, increased the rate of disinfection of yeast-cells to a degree disproportionate to the increase in concentration. They conclude that the absorption of the germicide is the first phase in the process of disinfection, and that this is followed by the chemical action of the germicide upon the cells, which is not affected by concentration in the same way as the absorption.

The object of the investigation described below was to obtain further knowledge of the relations of phenol and m-cresol to proteins with a view to understanding the nature of their germicidal action.

\section{The Method of Study}

\section{(a) The estimation of phenol and cresol}

The method used was that described by Lloyd ${ }^{3}$ in 1905 . It consists in the bromination of phenol in the presence of a large excess of hydrochloric acid, under which condition three bromine atoms are quantitatively introduced into the phenol molecule.

Some further experiments showed that it was also possible to employ this method for the accurate determination of meta-cresol. Accurate results, however, could not be obtained with ortho- and para-cresol. The relative positions of the hydroxyl and methyl groups in the cresol molecule evidently influence the entrance of bromine atoms into the benzene nucleus.

(b) The materials used

The proteins used were gelatin, precipitated casein, dialysed crystalline egg-albumen and heat-coagulated egg-globulin (the fraction of egg-white precipitated by $1 / 2$ saturated ammonium sulphate).

The gelatin (best gold label, Swiss) was first washed in running water for twenty-four hours. It was then air dried for twenty-four hours, cut into slips, and dried in a muslin bag at $110^{\circ} \mathrm{C}$. 
Merck's casein, prepared according to Hammarsten, was used in the experiments with casein.

The egg-albumen was prepared in the crystallized state from eggwhite by the method of Hopkins and Pinkus, described in 1898,4 and was dialysed for ten days, first of all, in tap-water and finally in distilled water. The heat-coagulum was prepared by heating the dialysed solution of the protein slightly acidified by a few drops of 1 per cent. acetic acid. The coagulum was well washed and dried at $105^{\circ} \mathrm{C}$.

The globulin fraction of egg-white was separated from the albumen as far as possible by several precipitations with half-saturated ammonium sulphate. The globulin was then dissolved in very dilute ammonium sulphate, coagulated by heat, washed free of ammonium sulphate and dried at $105^{\circ} \mathrm{C}$.

\section{(c) The experimental methods}

Experiments with gelatin.-A definite amount of gelatin in the form of slips about one inch by three inches was suspended in a known volume of an aqueous solution of phenol of estimated strength. When the maximum amount of phenol had been taken up by the protein-the equilibrium-time having been determined by some preliminary experiments-the strength of the aqueous phenol solution was again estimated. By a comparison of the initial and final concentrations the distribution of phenol between water and protein was determined. New equilibria with phenol between water and gelatin were obtained by withdrawing a known volume of the water-phase and replacing this with an equal volume of water or phenol solution.

Experiments with casein, egg-albumen and egg-globulin.-The suspended casein was so fine that it could not be completely removed by filtration. Accordingly, in the experiments with it, and also with eggalbumen and globulin, the method introduced by Moore and Bigland 5 was employed. This consists in restricting the protein to one region of the water-phase by means of a piece of dialysing paper, which was crumpled into the shape of a bag and enclosed in a stoppered bottle. Phenol was found to pass the dialyser readily. When equilibrium was attained, samples were removed for analysis from the portion of the water phase outside the dialyser. In other respects the procedure was similar to that adopted in the experiments with gelatin. All experiments were carried out at $20^{\circ} \mathrm{C}$. in a thermostat, except where otherwise stated. 


\title{
THE EXPERIMENTAL RESULTS
}

\begin{abstract}
I
The Influence of Concentration upon the Distribution of Phenol between Water and Proteins
\end{abstract}

(a) Gelatin

Phenol below concentrations of 2.6 per cent. caused no visible change in gelatin. When immersed in concentrations between $2 \cdot 6$ and 5 per cent. the gelatin became white and semi-transparent but did not lose its shape, and in concentrations above 5 per cent. it contracted, lost its form, and settled on the bottom of the vessel as a viscous mass. The precipitated protein was soluble in hot 5 per cent. phenol solutions, but on cooling the gelatin was reprecipitated, having lost the property of setting. These changes were revers $\approx$ when the supernatant liquid was poured off and replaced by water. In the case of the effects of concentrations less than 5 per cent., the protein quickly assumed its original appearance, except that it had acquired the property of swelling considerably, just as it does after immersion in acid. The reversibility was less rapid when the gelatin had been immersed in phenol concentrations above 5 per cent. The recovered gelatin was still soluble in warm water, and had regained the property of setting when the solution was cooled.

The time required for equilibrium.-The maximum amount of phenol was taken up by gelatin from concentrations less than 2.6 per cent. in two minutes. The reverse process was complete in fifteen minutes.

From concentrations of 2.6 per cent. to 5 per cent., namely, those which visibly changed the gelatin but did not prevent its suspension in water, the uptake of phenol was complete in twenty-four hours, and the reverse process was finished in the same time.

From concentrations of 5 to 7 per cent., causing the precipitation of the protein on the bottom of the vessel, the maximum amount of phenol was absorbed in forty-eight hours. The reverse process, however, required five weeks for its completion.

In concentrations from 0 to 26 per cent., at which point the gelatin was precipitated, the phenol was distributed between water and protein according to the partition-law. It was about three times as soluble in gelatin as in water.

At concentrations of about 2.6 per cent. the gelatin became white and opaque, and a greatly increased proportional uptake of phenol occurred. 
TABLE I

\section{EQUILIBRIA}

10 grams gelatin; 250 c.c. phenol solution

Water-phase

$\begin{array}{cc}\text { Initial phenol } & \text { Final phenol } \\ \text { concentration } & \begin{array}{c}\text { (grams per } \\ \text { concentration } \\ \text { (grams per }\end{array} \\ 100 \text { c.c.) } & 100 \text { c.c.) }\end{array}$

Experiment I-

(B)

(B)

(A)

$\mathbf{0} \cdot 990$
$1 \cdot 162$
$1 \cdot 813$
$\mathbf{2} \cdot 167$
$2 \cdot 365$
$2 \cdot 801$
$\mathbf{3} \cdot 077$
$\mathbf{3 \cdot 2 5 5}$
$\mathbf{3} \cdot 399$
$\mathbf{3} \cdot 816$
$4 \cdot 272$
$4 \cdot 535$
$\mathbf{5} \cdot 625$
$5 \cdot 976$
$6 \cdot 283$
$6 \cdot 489$

Amount of phenol

$$
\text { in grams }
$$

absorbed by

1 gram gelatin (by difference)
Distribution-ratio Amount of phenol held by 1 gram gelatin

Amount of phenol held by 1 gram water

Experiment II (Diagram I).-1.02 grams gelatin ; 60 c.c. phenol solution

Water-phase

Initial phenol concentration (grams per 100 c.c.)

Final phenol
concentration
(grams per
100 c.c.)

Amount of phenol

in grams
absorbed by
1 gram gelatin

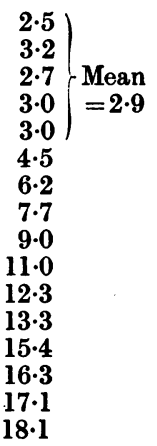

(A)

\begin{tabular}{|c|c|c|}
\hline 0.410 & $0 \cdot 390$ & 0.0123 \\
\hline 0.575 & 0.551 & 0.014 \\
\hline 0.739 & 0.706 & 0.019 \\
\hline $1 \cdot 889$ & $1 \cdot 791$ & 0.057 \\
\hline 2.518 & $2 \cdot 402$ & 0.068 \\
\hline $2 \cdot 665$ & $2 \cdot 566$ & $0 \cdot 075$ \\
\hline $3 \cdot 778$ & $3 \cdot 246$ & 0.313 \\
\hline $4 \cdot 080$ & $3 \cdot 609$ & 0.352 \\
\hline $5 \cdot 037$ & 4.008 & 0.605 \\
\hline $6 \cdot 296$ & $4 \cdot 838$ & 0.858 \\
\hline 6.561 & $5 \cdot 510$ & 0.970 \\
\hline $7 \cdot 556$ & $5 \cdot 606$ & $1 \cdot 150$ \\
\hline $2 \cdot 419$ & $3 \cdot 244$ & $0 \cdot 373$ \\
\hline 0.934 & $2 \cdot 707$ & $0 \cdot 104$ \\
\hline 0.540 & $1 \cdot 122$ & 0.031 \\
\hline 0.561 & 0.579 & 0.020 \\
\hline 0.386 & 0.392 & 0.017 \\
\hline
\end{tabular}

N.B.-(A) Equilibria obtained whilst phenol concentration was increased (B). Equilibria obtained by reverse process. 
With further increase in concentration the distribution-ratio continued to rise. No evidence of saturation of the gelatin with phenol was obtained, although the saturation point in water was closely approached.

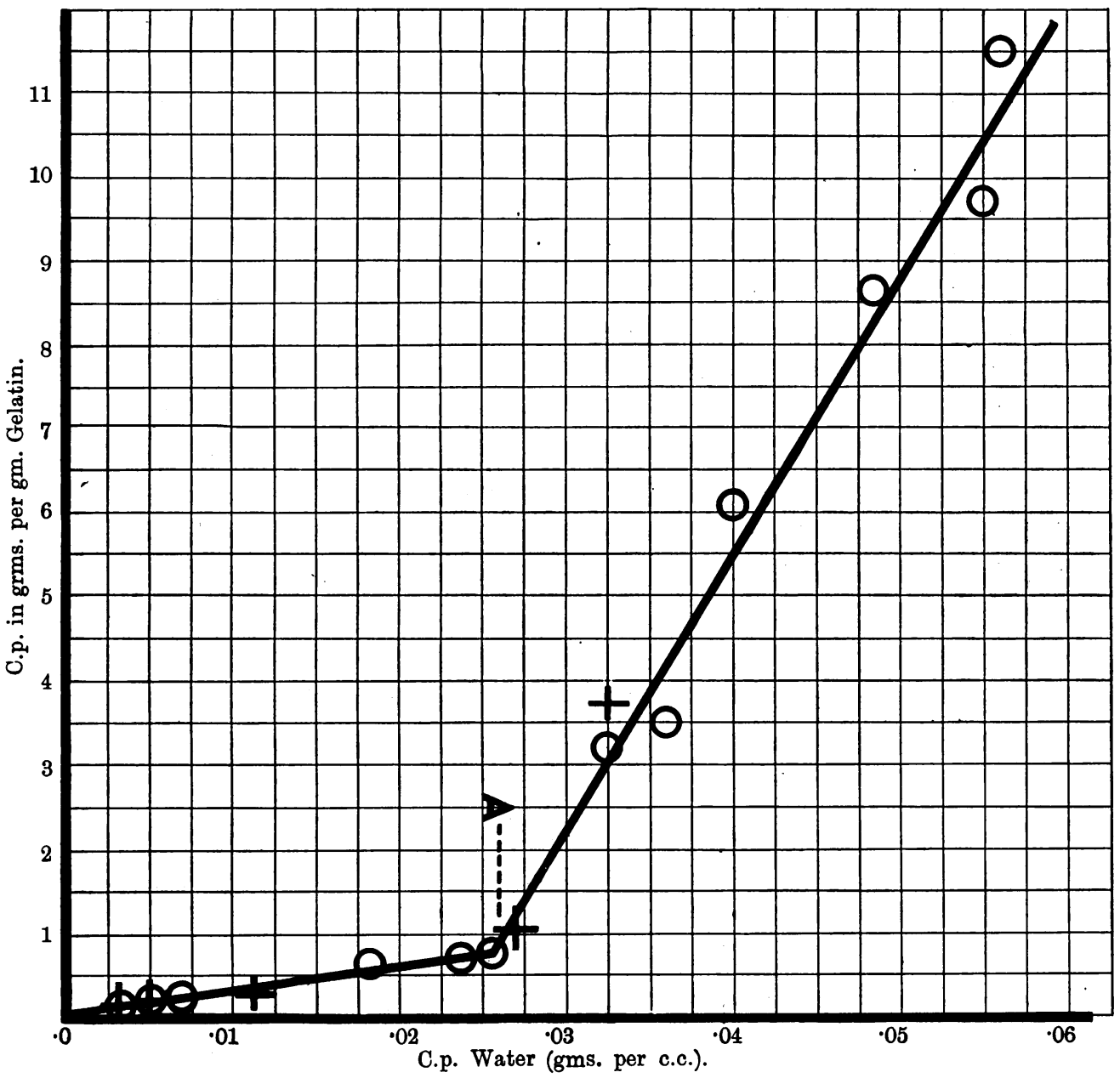

Diagram I.-Equilibria with phenol between water and gelatin showing influence of phenol. coagulation upon the distribution of phenol between water and protein. (Experiment II, Table I).

$\mathbf{O}=$ Equilibria obtained during rising concentration of phenol.

$+=$ Equilibria obtained by reverse process.

$\mathbf{A}=$ Commencement of precipitation of protein. 
The equilibria (A) in Experiments I and II were obtained whilst the concentration of phenol was successively raised, and equilibria (B) by the reverse process. The approximate coincidence of the two series of equilibria, indicated by Diagram I, shows that the absorption of phenol by gelatin is a reversible process throughout the whole range of concentration investigated. The precipitation at 2.6 per cent. is also reversible.

It appears that, although unprecipitated gelatin below concentrations of 26 per cent. absorbs phenol according to the partition-law, when the concentration of phenol in the water reaches about 2.6 per cent. the phenol enters into a new relationship with the gelatin with the result that the protein undergoes precipitation and its absorptive capacity for phenol is enormously increased. The experiments on the distribution of phenol between water and gelatin did not afford good results when higher concentrations of phenol were employed, as equilibria were difficult to obtain. The precipitation of the gelatin in concentrations above 2.6 per cent. seems to be responsible for the somewhat erratic results. Nevertheless, the observational points plotted in diagram 1 evidently indicate again a linear relation to concentration, but in this case the uptake of phenol by the gelatin is proportional, not to the total concentration of phenol in the water-phase, but to this less 2.6 per cent. What the significance of this may be I am unable to suggest, but it is evidently associated with the sudden change in condition of the gelatin on precipitation.

\section{(b) Egg-albumen in solution}

Egg-albumen was more sensitive than gelatin to the precipitating action of phenol. A 10 per cent. suspension of gelatin in water was not visibly affected until the phenol concentration reached about 2.6 per cent., whereas a 10 per cent. solution of egg-albumen was rendered turbid by 1 per cent. phenol, slightly precipitated by $1 \frac{1}{2}$ per cent., and completely precipitated by 2 per cent. phenol. Smaller concentrations of egg-albumen were affected by still lower phenol concentrations. The precipitates of egg-albumen were stable on the addition of water.

The absorption of phenol by unprecipitated egg-albumen and the reverse process were both complete within twenty-four hours. In the case of the protein precipitated by phenol the equilibrium approached from either side was attained within ninety-six hours. 
TabLe II

\section{EQUILIBRIA}

\begin{tabular}{|c|c|c|c|c|}
\hline \multicolumn{2}{|c|}{ Water-phase } & \multirow{3}{*}{$\begin{array}{l}\text { Amount of phenol } \\
\text { held by } 1 \text { gram } \\
\text { of egg-albumen } \\
\text { in grams } \\
\text { (by } \\
\text { difference) }\end{array}$} & & $\begin{array}{l}\text { Distribution-ratio } \\
\text { Amount of }\end{array}$ \\
\hline \multirow{2}{*}{$\begin{array}{c}\text { Initial } \\
\text { concentration } \\
\text { (grams per } \\
100 \text { c.c.) }\end{array}$} & \multirow{2}{*}{$\begin{array}{c}\text { Final } \\
\text { concentration } \\
\text { (grams per } \\
100 \text { c.c.) }\end{array}$} & & State of & $\begin{array}{l}\text { phenol held by } \\
1 \text { gram protein }\end{array}$ \\
\hline & & & & $\begin{array}{c}\text { Amount of phenol } \\
\text { held by } 1 \text { gram } \\
\text { water }\end{array}$ \\
\hline
\end{tabular}

$\dot{E}$ xperiment I (Diagram II). - 10 c.c. $16 \cdot 47$ per cent. egg-albumen solution; 50 c.c. phenol solution

\begin{tabular}{|c|c|c|c|c|c|}
\hline (B) & $0 \cdot 251$ & $0 \cdot 237$ & 0.005 & Unprecipitated & $2 \cdot 1$ Mean \\
\hline (B) & 0.332 & 0.312 & 0.007 & , & $2 \cdot 3=2 \cdot 2$ \\
\hline (B) & 0.805 & 0.757 & 0.025 & Turbid & $\mathbf{3 \cdot 3}$ \\
\hline (B) & $1 \cdot 259$ & $1 \cdot 055$ & 0.074 & Slightly precipitated & $7 \cdot 1$ \\
\hline (B) & $1 \cdot 666$ & $1 \cdot 332$ & 0.122 & Precipitated & $9 \cdot 1$ \\
\hline (B) & $4 \cdot 233$ & $3 \cdot 229$ & 0.365 & $"$ & $11 \cdot 3$ \\
\hline (A) & 0.777 & 0.874 & 0.086 & $\eta$ & $9 \cdot 8$ \\
\hline (A) & 0.510 & 0.579 & 0.0614 & " & 10.5 \\
\hline
\end{tabular}

Experiment II.-10 c.c. $9 \cdot 62$ per cent. albumen solution; 50 c.c. phenol solution

$\left.\begin{array}{llllcr}\text { (B) } & 0.138 & 0.132 & 0.004 & \text { Unprecipitated } & 3.0 \\ \text { (B) } & 0.214 & 0.203 & 0.007 & \# & 3.5 \\ \text { (B) } & 0.712 & 0.695 & 0.015 & n & 2.1 \\ \text { (B) } & 0.971 & 0.938 & 0.035 & \text { Turbid } & 3.7\end{array}\right\}=3.1$

N.B.-(B) Equilibra obtained by uptake of phenol.

(A) Equilibria obtained by reverse process. 


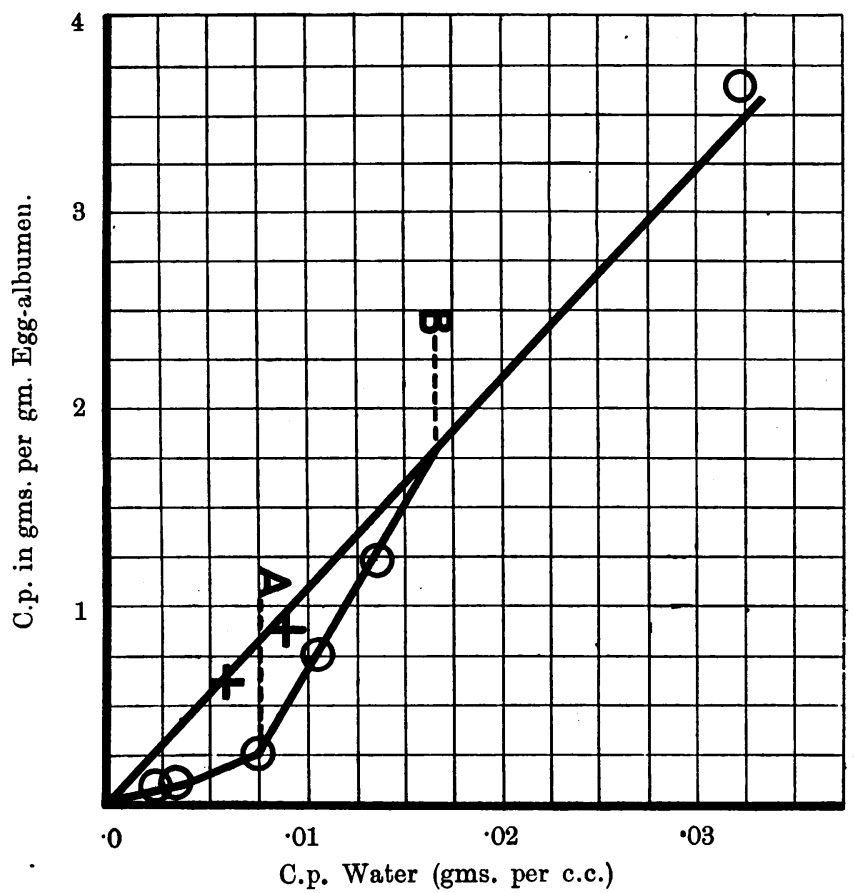

DIAGRAM II.-Equilibria with phenol between water and egg-albumen showing the influence of phenol-coagulation on the distribution of phenol between water and protein. (Experiment I, Table II).

$\mathrm{O}=$ Equilibria obtained during rising concentration of phenol.

$+=$ Equilibria obtained by reverse process.

$\mathbf{A}=$ Commencement of precipitation. ${ }^{-} \quad \mathbf{B}=$ Completion of precipitation.

Experiment III.-10 c.c. 102 per cent. egg-albumen solution ; 50 c.c. phenol solution

Water-phase

Initial
concentrati
(grams p
100 c.c.)
$0 \cdot 164$
$0 \cdot 410$
$0 \cdot 639$
$0 \cdot 737$
$0 \cdot 877$
$2 \cdot 148$
$4 \cdot 926$
$4 \cdot 651$
$5 \cdot 475$
$6 \cdot 056$
$3 \cdot 346$
$1 \cdot 444$
0.708
0.360
0.184
0.096

Final concentration (grams per

(B)

(B)

(B)

(B)

(B)

(B)

(B)

(B)

(B)

(B)

(A)

(A)

(A)

(A)

(A)

(A)
100 c.c.)

$0 \cdot 155$

$0 \cdot 390$

$0 \cdot 623$

$0 \cdot 727$

$0 \cdot 857$

$1 \cdot 807$

$3 \cdot 466$

$4 \cdot 235$

$5 \cdot 280$

$5 \cdot 742$

$3 \cdot 812$

$1 \cdot 699$

0.864

0.441

0.231

0.119
Amount of phenol

in grams
taken up by $\quad$ State of

taken up by (by protein

Distribution-ratio difference)

\begin{tabular}{|c|c|c|c|}
\hline 0.005 & Unprecipitated & $3 \cdot 2$ & \\
\hline 0.012 & ", & 3.0 & \\
\hline 0.014 & 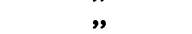 & $2 \cdot 3$ & Mean \\
\hline 0.018 & , & $2 \cdot 5$ & $=2.9$ \\
\hline 0.030 & , & $3 \cdot 5$ & \\
\hline $0 \cdot 215$ & Precipitated & $11 \cdot 9$ & \\
\hline 0.376 & ", & $10 \cdot 8$ & \\
\hline 0.460 & ", & $10 \cdot 9$ & \\
\hline 0.575 & 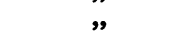 & 10.9 & \\
\hline $0 \cdot 760$ & 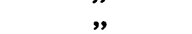 & $13 \cdot 2$ & \\
\hline 0.486 & $"$ & $12 \cdot 7$ & \\
\hline $0 \cdot 226$ & $"$ & $13 \cdot 3$ & \\
\hline $0 \cdot 134$ & 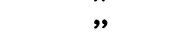 & $15 \cdot 5$ & \\
\hline 0.086 & " & 19.5 & \\
\hline 0.059 & ", & $25 \cdot 5$ & \\
\hline 0.046 & $"$ & $38 \cdot 7$ & \\
\hline
\end{tabular}


Experiment $I V .-10 \cdot 2$ per cent. egg-albumen solution; 50 c.c. phenol solution

(B)

(B)

(A)

(A)

$\begin{array}{ll}0.400 & 0.383 \\ 0.400 & 0.387 \\ 0.258 & 0.262 \\ 0.258 & 0.262\end{array}$

$\mathbf{0 . 0 1 1}$
$\mathbf{0 . 0 1 0}$
$\mathbf{0 . 0 0 9}$
$\mathbf{0 . 0 0 8}$

Unprecipitated
$"$
$"$

$\left.\begin{array}{l}2 \cdot 9 \\ 2 \cdot 6 \\ 3.4 \\ 3 \cdot 1\end{array}\right\}=3 \cdot 0$
Mean

N.B.-(B) Equilibria obtained whilst phenol concentration was rising,

(A) Equilibria obtained by reverse process.

The results obtained show that the distribution of phenol between water and unprecipitated egg-albumen followed the partition-law, and that phenol was on the average 2.8 times as soluble in the protein as in water. The absorption of phenol by the egg-albumen was reversible.

A comparison of the above results with those of the experiments with gelatin indicates that the solubilities of phenol in egg-albumen and gelatin were approximately equal. Since egg-albumen was precipitated by much lower phenol concentrations than gelatin, there was therefore no relationship between their susceptibilities to precipitation and their absorptive capacities for phenol.

In the neighbourhood of 1.0 per cent. final concentration of phenol, where the precipitation of egg-albumen commenced, as indicated in Diagram II, there was a greatly increased proportional uptake of phenol, and with rising concentration the distribution-ratio continued to increase until precipitation was complete (at about $1 \frac{1}{2}$ per cent. final concentration). With further rise in concentration the uptake of phenol by the protein again became proportional to the concentration in the water, but with a higher partition-coefficient than at the commencement.

The observations on equilibria, made as the concentration of phenol in the water was being successively diminished, show that the egg-albumen once having been irreversibly precipitated by phenol maintains the high absorptive capacity for this substance until the concentration of phenol in the water is reduced to zero. Although with diminishing concentration the coagulated albumen gave up some of its absorbed phenol, so that in low concentrations it only retained a very small amount, the protein remained permanently denatured. It would appear that the denatured albumen is not an intimate phenol-protein complex, but is some modification of the original protein, which possesses a high solvent power for phenol. 


\title{
(c) Egg-albumen coagulated by heät
}

\section{TABLE III}

\section{EQUILIBRIA}

\begin{tabular}{ccc} 
Water-phase & Weight of \\
$\begin{array}{c}\text { Initial } \\
\text { concentration } \\
\text { (grams per } \\
100 \text { c.c.) }\end{array}$ & $\begin{array}{c}\text { Final } \\
\text { concentration } \\
\text { (grams per }\end{array}$ & $\begin{array}{c}\text { coagulum } \\
\text { taken } \\
\text { in grams }\end{array}$ \\
\hline 100 c.c.) &
\end{tabular}

Amount of phenol Distribution-ratio in grams phenol held by absorbed by 1 gram coagulum 1 gram coagulum (by
difference)
$\begin{gathered}\text { Amount of phenol by } 1 \text { gram } \\ \text { water }\end{gathered}$

Experiment I. -25 c.c. phenol solution

$\left.\begin{array}{llllr}4.916 & 4.054 & 0.5 & 0.431 & 10 \cdot 6 \\ 1.992 & 1.682 & 0.5 & 0.155 & 9 \cdot 2 \\ 0.987 & 0.822 & 0.5 & 0.082 & 10.0 \\ 0.984 & 0.703 & 1.0 & 0.070 & 10.0 \\ 0.584 & 0.515 & 0.35 & 0.049 & 9.5\end{array}\right\}=9 \cdot 8$

(A)

(B)

(A)

(B)

Experiment II (Diagram III).-25 c.c. phenol solution

$$
\begin{aligned}
& 6.512 \\
& 2.076 \\
& 0.495 \\
& 0.159
\end{aligned}
$$

\begin{abstract}
$5 \cdot 190$
$2 \cdot 706$

$0 \cdot 399$

0.198
\end{abstract}

0.5
0.5
0.5
0.5

0.661

0.346

0.048

0.028

$\left.\begin{array}{l}12 \cdot 7 \\ 12 \cdot 8 \\ 12 \cdot 0 \\ 14 \cdot 2\end{array}\right\}=12 \cdot 9$
Mean

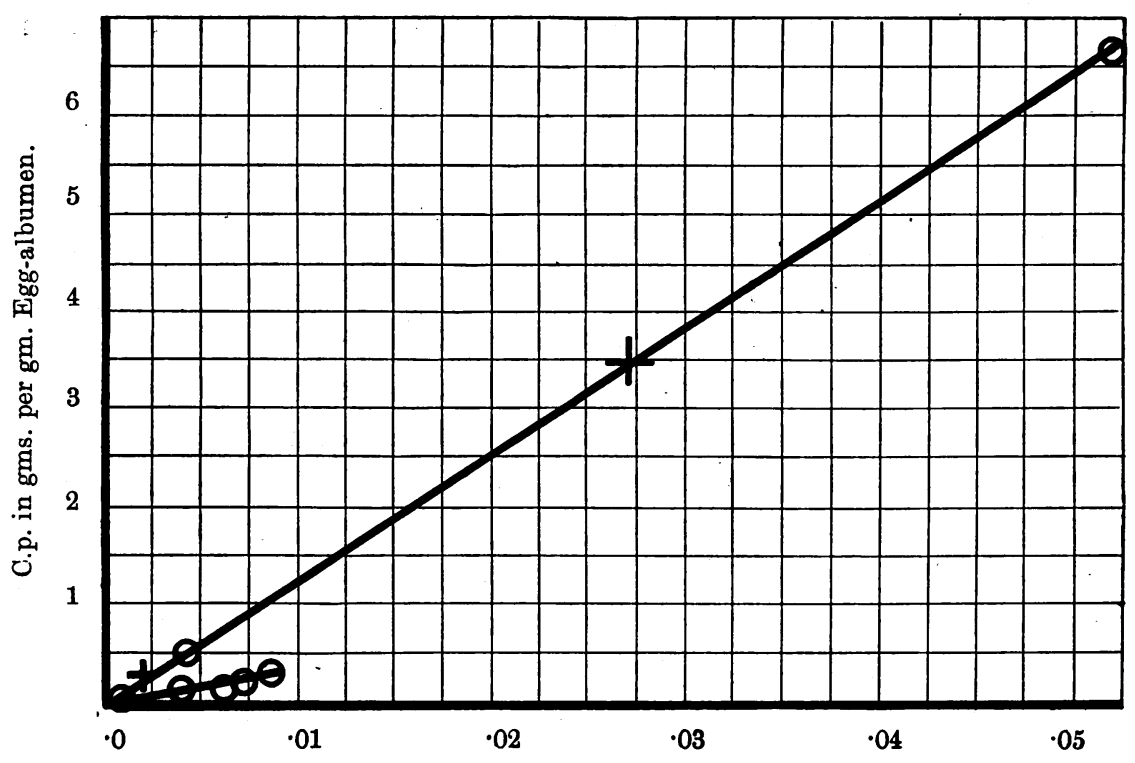

C.p. Water (gms. per c.c.).

DiAgram III.-Equilibria with phenol between water and egg-albumen showing the influence of heat-coagulation on the distribution of phenol between water and protein.

Lower Curve.-Unprecipitated protein. (Experiment III, Table II).

Upper Curve.-Heat-coagulated protein. (Experiment II, Table III).

$\mathbf{O}=$ Equilibria obtained during rising concentration of phenol.

$+=$ Equilibria obtained by reverse process. 
The distribution of phenol between heat-coagulated egg-albumen and water therefore followed the partition-law.

In Experiment II, equilibria (A) were obtained by the uptake of phenol by the coagulum, and equilibria (B) by the reverse process. The similarity in the values of the distribution-ratios deduced from the two series of equilibria showed that the absorption was reversible.

The mean partition-coefficient in Experiment $I$ was 9.8, while in Experiment II it was 12.9. The coagula used were prepared from different batches of albumen. This may explain the difference in these values which, however, may also have its explanation in the varying conditions existing during the formation of the heat-coagula.

A comparison of the solvent power of the heat-coagulum for phenol with that of unprecipitated egg-albumen and of the phenol precipitated protein (Tables II and III) indicates that heat-coagulation was accompanied by an increase in the absorptive capacity of this protein for phenol, and that, except in low concentrations, heat- and phenolcoagulation affected the distribution of phenol between egg-albumen and water to somewhat similar degrees. Moore and Bigland 5 showed that the uptake of alkali by egg-albumen was also increased by heatcoagulation.

(d) Heat-coagulated egg-globulin

\section{TABLE IV}

\section{EQUILIBRIA}

$\frac{1}{2}$ gram coagulum; 25 c.c. phenol solution

Water-phase

Initial concentration (grams per 100

c.e.)

$5 \cdot 195$

4.632

4.572

$1 \cdot 977$

0.505

$0 \cdot 373$

$0 \cdot 166$

$\mathbf{0 . 2 4 7}$
Final concentration (grams per 100 c.c.)

$4 \cdot 470$

$3 \cdot 871$

3.810

$1 \cdot 653$

0.416

0.342

$0 \cdot 201$

$0 \cdot 199$
Amount of phenol in grams taken up by 1 gram coagulum

\begin{tabular}{|c|}
\hline $\begin{array}{c}\text { Distribution-ratio } \\
\text { Amount of phenol } \\
\text { held by } 1 \text { gram } \\
\text { protein }\end{array}$ \\
\hline $\begin{array}{l}\text { Amount of phenol } \\
\text { held by } 1 \text { gram } \\
\text { water }\end{array}$ \\
\hline 11.7 \\
\hline 10.8 \\
\hline 10.7 \\
\hline $9 \cdot 8$ \\
\hline $10 \cdot 6$ \\
\hline $11 \cdot 4$ \\
\hline $13 \cdot 5$ \\
\hline $12 \cdot 0$ \\
\hline
\end{tabular}

Distribution-ratio mount of phenol eld by 1 gram

Amount of phenol by 1

0.524

0.420

0.408

0.162

$0 \cdot 044$

0.039

0.027

0.024 
The distribution of phenol between water and the coagulated globulin therefore followed the partition-law, and phenol was 11.3 times as soluble in the protein as in water. By comparing the above results with those in Table III it is found that the solubilities of phenol in heat-coagulated egg-albumen and globulin were approximately the same.

\section{(e) Casein}

Casein was not precipitated from its solutions in sodium hydroxide by phenol. The experiments described below were carried out with the precipitated casein of commerce. The maximum amount of phenol was absorbed by casein in forty hours, which time was therefore allowed for equilibrium to be established.

TABLE V

\section{EQUILIBRIA}

$\frac{1}{2}$ gram casein ; 25 c.c. phenol solution

\begin{tabular}{|c|c|c|}
\hline Water-phas & & Amount of phenol \\
\hline $\begin{array}{c}\text { nitial concentration } \\
\text { (grams per } 100 \\
\text { c.c.) }\end{array}$ & $\begin{array}{c}\text { Final concentration } \\
\text { (grams per } 100 \\
\text { c.c.) }\end{array}$ & $\begin{array}{c}\text { casein } \\
\text { (by difference) }\end{array}$ \\
\hline
\end{tabular}

Distribution-ratio

Amount of phenol held by 1 gram protein

Amount of phenol held by 1 gram

Experiment I (Diagram IV)

\begin{tabular}{|ccc}
1 & $7 \cdot 485$ & $5 \cdot 614$ \\
2 & $5 \cdot 233$ & $4 \cdot 418$ \\
3 & $4 \cdot 491$ & $3 \cdot 491$ \\
4 & $1 \cdot 396$ & $1 \cdot 888$ \\
5 & $1 \cdot 497$ & $1 \cdot 227$ \\
6 & $0 \cdot 491$ & $0 \cdot 633$ \\
7 & $0 \cdot 253$ & $0 \cdot 315$ \\
8 & $0 \cdot 126$ & $0 \cdot 156$ \\
Experiment II & $0 \cdot 409$ & $0 \cdot 344$ \\
2 & $1 \cdot 137$ & 0.986 \\
3 & 3.634 & $3 \cdot 125$ \\
4 & 4.966 & $4 \cdot 508$ \\
5 & 5.527 & $5 \cdot 266$
\end{tabular}

0.936
0.662
0.500
0.254
0.135
0.064
0.033
0.018
0.033
0.108
0.363
0.592
0.722

$16 \cdot 6$

$15 \cdot 0$

$14 \cdot 3$

$13 \cdot 5$

11.0

$10 \cdot 1$

$10 \cdot 4$

11.5

$9 \cdot 6$

11.0

$11 \cdot 6$

$13 \cdot 1$

$13 \cdot 7$ 


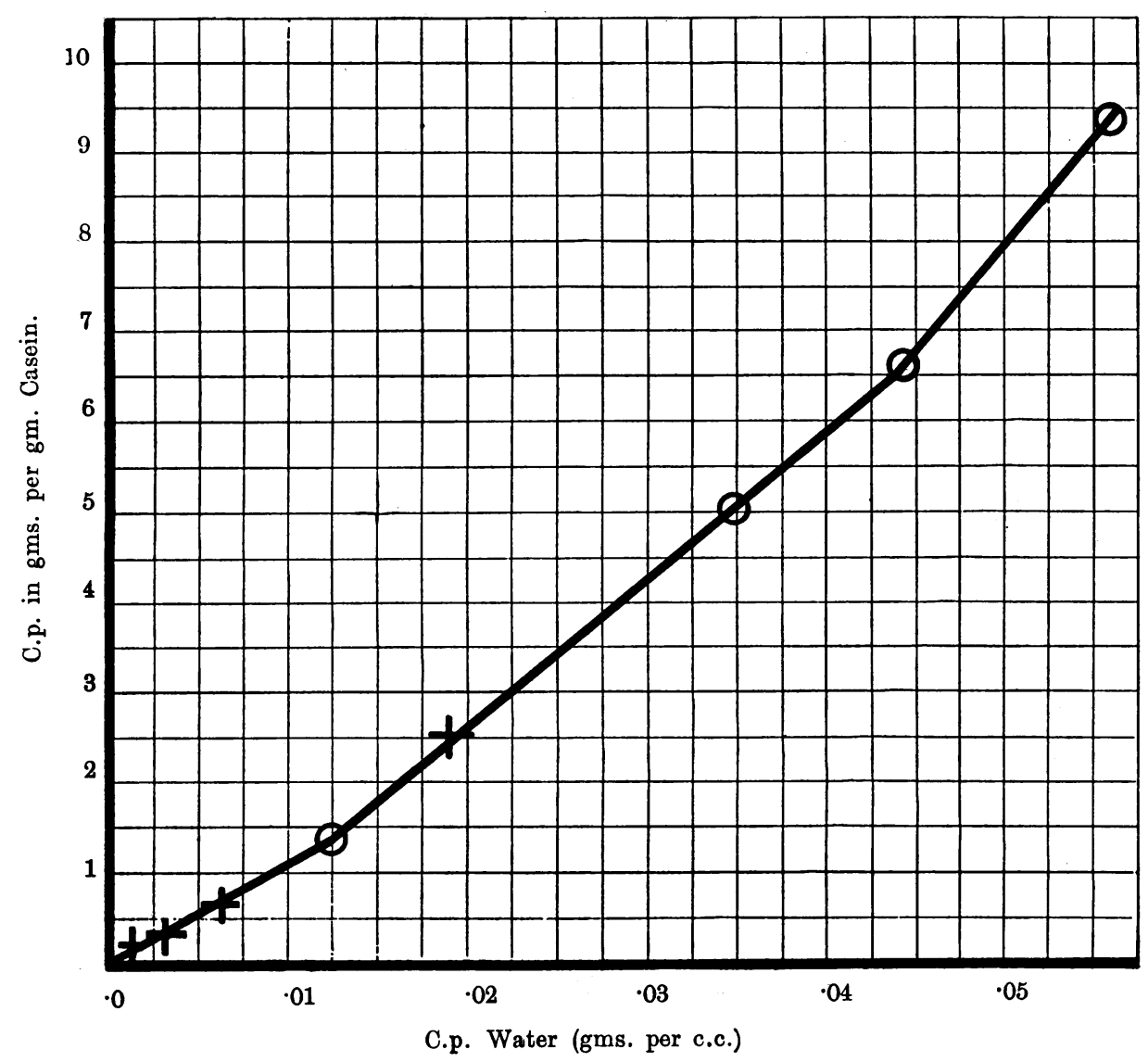

Diagram IV.-Equilibria with phenol between water and casein. (Experiment I, Table V.)

$\mathrm{O}=$ Equilibria obtained during rising phenol concentration.

$+=$ Equilibria obtained by reverse process.

The absorptive capacity of casein for phenol was thus considerably greater than that of water, and was of the same order of magnitude as the absorptive capacities of other precipitated proteins for this substance. The results of Experiment I indicated that although below a final phenol concentration of 1.8 per cent., the distribution of phenol between water and casein followed the partition-law, at 1.8 per cent. there was a deviation therefrom, the distribution-ratio increasing with further rise in concentration. The results of Experiment II also indicated this deviation, but there were not sufficient equilibria determined in this 
experiment to show the constancy in magnitude of the distribution-ratio at low concentrations.

Equilibria 1, 2, 3, 5, in Experiment I were obtained by the uptake of phenol by casein; the remaining equilibra by the reverse process. The coincidence of the two series (Diagram IV) showed that the absorption of phenol by casein was reversible.

\section{II}

The Influence of Temperature upon the Distribution of Phenol between Water and Proteins

(a) Egg-albumen in solution

In the following table are given the amounts of phenol absorbed by a definite amount of protein from the same concentration at $20^{\circ} \mathrm{C}$. and $37 \cdot 5^{\circ} \mathrm{C}$.

TABLI VI.-10 c.c. 11.2 per cent. egg-albumen solution; 50 c.c. phenol solution

Water-phase

Tempera- Initial concentration Final concentration ture (grams per 100 c.c.)

$\begin{array}{ll}20^{\circ} \mathrm{C} . & 0 \cdot 248 \\ 20^{\circ} \mathrm{C} . & 0 \cdot 248\end{array}$

$37 \cdot 5^{\circ} \mathrm{C}$. $\quad 0.248$ (grams per 100 c.c.)

$0 \cdot 196$

$0 \cdot 196$

$0 \cdot 197$
Amount of phenol in grams taken up by 1.0 gram protein

A rise in temperature of $17.5^{\circ} \mathrm{C}$. thus had no measurable effect upon the uptake of phenol by unprecipitated egg-albumen.

\section{(b) Heat-coagulated egg-albumen}

The experiments with the heat-coagulum were also carried out at $20^{\circ} \mathrm{C}$. and $37 \cdot 5^{\circ} \mathrm{C}$.

TABLE VII

\section{EQUILIBRIA}

\begin{tabular}{|c|c|c|}
\hline \multirow[b]{2}{*}{$\begin{array}{l}\text { Tempera- } \\
\text { ture }\end{array}$} & \multicolumn{2}{|c|}{ Water-phase $=25$ c.c. } \\
\hline & $\begin{array}{c}\text { Initial } \\
\text { concentration } \\
\text { (grams per } \\
100 \text { c.c.) }\end{array}$ & $\begin{array}{c}\text { Final } \\
\text { concentration } \\
\text { (grams per } \\
100 \text { c.c.) }\end{array}$ \\
\hline $\begin{array}{l}20^{\circ} \mathrm{C} \text {. } \\
20^{\circ} \mathrm{C} \text {. } \\
20^{\circ} \mathrm{C} \text {. } \\
37 \cdot 5^{\circ} \mathrm{C} \text {. } \\
37 \cdot 5^{\circ} \mathrm{C} \text {. } \\
37 \cdot 5^{\circ} \mathrm{C} \text {. }\end{array}$ & $\begin{array}{l}0.584 \\
0.984 \\
0.984 \\
0.984 \\
0.984 \\
0.584\end{array}$ & $\begin{array}{l}0.515 \\
0.702 \\
0.705 \\
0.731 \\
0.732 \\
0.524\end{array}$ \\
\hline
\end{tabular}

Amount of phenol in grams taken up by Distribution-ratio the coagulum

$\begin{array}{rr}0.017 & 9 \cdot 7 \\ 0.070 & 10 \cdot 0 \\ 0.070 & 9 \cdot 9 \\ 0.063 & 8 \cdot 6 \\ 0.063 & 8 \cdot 6 \\ 0.015 & 8 \cdot 2\end{array}$

The results show that the uptake of phenol by the coagulum was slightly decreased by a rise in temperature from $20^{\circ} \mathrm{C}$. to $37 \cdot 5^{\circ} \mathrm{C}$. 


\section{(c) Gelatin}

As gelatin dissolves in water at temperatures above $20^{\circ} \mathrm{C}$, experiments were carried out at lower temperatures.

TABLE VIII

EQUILIBRIA

Gelatin, 4 grams; phenol solution, 100 c.c.

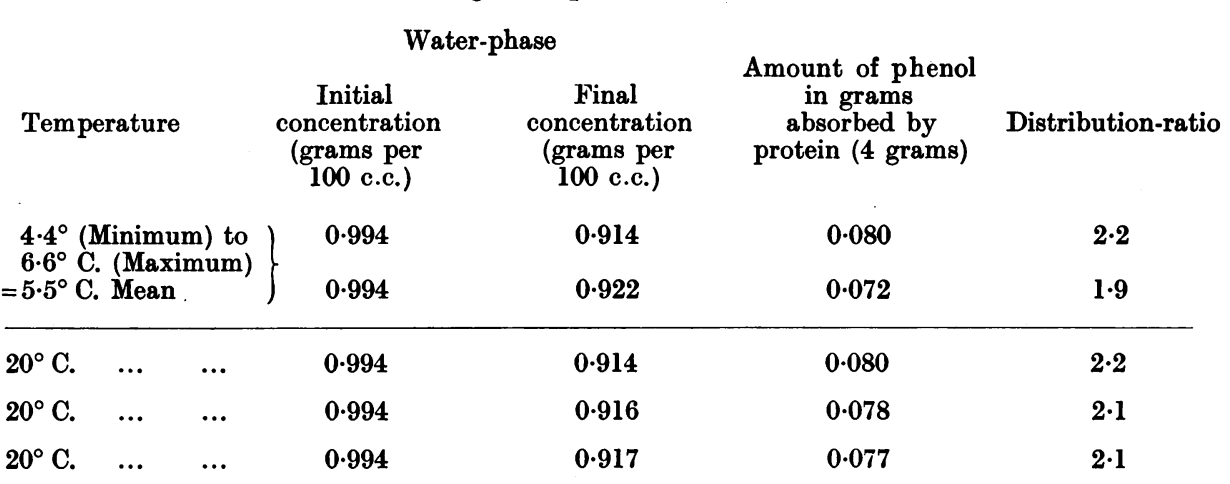

A rise in temperature of about $15^{\circ} \mathrm{C}$. therefore caused no change in the distribution of phenol between water and gelatin.

The results indicate that, although the solubilities of phenol in water, gelatin and dissolved egg-albumen were increased equally by rise in temperature, the solubility of phenol in heat-coagulated egg-albumen was increased to a slightly smaller extent than that of the same substance in water.

\section{III}

The Influence of Alcohol upon the Distribution of Phenol between Water and Heat-coagulated EgG-Albumen

A definite amount of coagulum was added to each of a number of phenol solutions containing different percentages by volume of alcohol. The mixtures were kept at $20^{\circ} \mathrm{C}$. for four days, and the filtrates from the coagula then analysed. Alcohol was found not to interfere with the process of estimating phenol. The results are tabulated below. 
TABLE IX.-1 gram coagulum ; 100 c.c. phenol solution

\begin{tabular}{|c|c|c|c|c|}
\hline \multicolumn{2}{|c|}{ Water-phase } & \multirow{3}{*}{$\begin{array}{c}\text { Per cent. of alcohol } \\
\text { initially } \\
\text { present } \\
\text { (by volume) }\end{array}$} & \multirow{3}{*}{$\begin{array}{l}\text { Amount of phenol } \\
\text { in grams } \\
\text { taken up by } \\
1 \text { gram of protein } \\
\text { (by difference) }\end{array}$} & \multirow{2}{*}{$\begin{array}{c}\text { Distribution-ratio } \\
\text { Amount of } \\
\text { phenol held by } \\
1 \text { gram protein }\end{array}$} \\
\hline Initial & Final & & & \\
\hline $\begin{array}{l}\text { (grams per } \\
100 \text { c.c.) }\end{array}$ & $\begin{array}{l}\text { (grams per } \\
100 \text { c.c.) }\end{array}$ & & & $\begin{array}{l}\text { Amount of phenol } \\
\text { held by } 1 \text { gram } \\
\text { water }\end{array}$ \\
\hline 1.992 & $1 \cdot 680$ & 0 & 0.156 & $9 \cdot 3$ \\
\hline 1.992 & 1.684 & 0 & $0 \cdot 154$ & 9. \\
\hline 0.993 & 0.833 & 0 & 0.080 & $9 \cdot 6$ \\
\hline 1.992 & 1.758 & 25 & $0 \cdot 117$ & $6 \cdot 7$ \\
\hline 1.992 & 1.770 & 25 & $0 \cdot 113$ & 6.4 \\
\hline 0.993 & 0.974 & 50 & 0.010 & $1 \cdot 0$ \\
\hline
\end{tabular}

These experiments indicate that alcohol considerably decreased the uptake of phenol by the protein. The alcohol as well as the phenol would be absorbed by the coagulum and, since alcohol is a very efficient solvent for phenol, its distribution between water and protein would lead to an increased solubility of phenol in both phases. The results of the above experiments therefore mean that the amount of alcohol absorbed was not sufficiently great to increase the solvent power of the protein for phenol to as great an extent as the alcohol unabsorbed increased the solvent power of the water for this substance.

\section{IV}

\section{The Influence of Hydrochloric Acid upon the Distribution of}

\section{Phenol between Water and Heat-Coagulated Egg-Albumen}

Hydrochloric acid decreases the solubility of phenol in water, and it was therefore of interest to investigate its influence on the distribution of phenol between water and proteins. Definite amounts of the coagulum were immersed in a number of phenol solutions containing different concentrations of hydrochloric acid. After equilibrium was established, the phenol contents of the filtrates were estimated. The results are tabulated below.

TABLE X. -0.5 gram coagulum; 25 c.c. phenol solution

Water-phase

$\begin{array}{cc}\begin{array}{c}\text { Initial } \\ \text { concentration } \\ \text { (grams per } \\ 100 \text { c.c.) }\end{array} & \begin{array}{c}\text { Final } \\ \text { concentration } \\ \text { (grams per } \\ 100 \text { c.c.) }\end{array} \\ & \\ \text { Experiment I } & \\ 0.996 & 0.824 \\ 0.996 & 0.793 \\ 0.996 & 0.805 \\ \text { Experiment II } & \\ 0.983 & 0.808 \\ 0.983 & 0.784 \\ 0.983 & 0.797 \\ 0.983 & 0.801\end{array}$

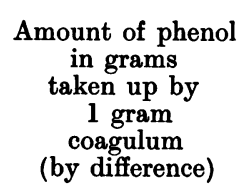
coagulum
(by difference)

0
$N \times 3$
$N \times 6$

0
$N \times 3$
$N \times 5$
$N \times 5$

Distribution-ratio

Amount of phenol

taken up by

1 gram protein of acid ( $\mathrm{HCl})$

Amount of phenol taken up by 1 gram water

$10 \cdot 3$

$12 \cdot 7$

$11 \cdot 8$

$10 \cdot 7$

$12 \cdot 7$

$11 \cdot 7$

$11 \cdot 3$ 
The presence of hydrochloric acid therefore slightly increased the uptake of phenol by the coagulum, but the increase was more marked in lower concentrations of acid than in higher ones.

The hydrochloric acid, as well as the phenol, would be absorbed by the protein, and it would seem that the amount of acid absorbed was not sufficient to decrease the solubility of phenol in the protein to as great an extent as the amount of acid left in aqueous solution decreased the solubility of phenol in water.

On comparing the results of the experiments with alcohol and acid with those of Reichel's 1 experiments on the influence of sodium chloride upon the uptake of phenol by proteins (see introduction), it is found that a substance increasing the solubility of phenol in water diminishes the uptake of phenol by a protein, while substances decreasing the solubility have exactly the opposite effect.

\section{V}

\section{The Influence of Concentration upon the Distribution of Meta-cresol between Water and Proteins}

\section{(a) Gelatin}

Saturated aqueous solutions (1·25 per cent.) of ortho-, meta- and para-cresols had no precipitating action upon gelatin. Below are tabulated some equilibria with meta-cresol between water and gelatin, and also some equilibria with phenol determined under the same conditions.

TABLE XI.-5 grams gelatin ; 125 c.c. phenol or cresol solution

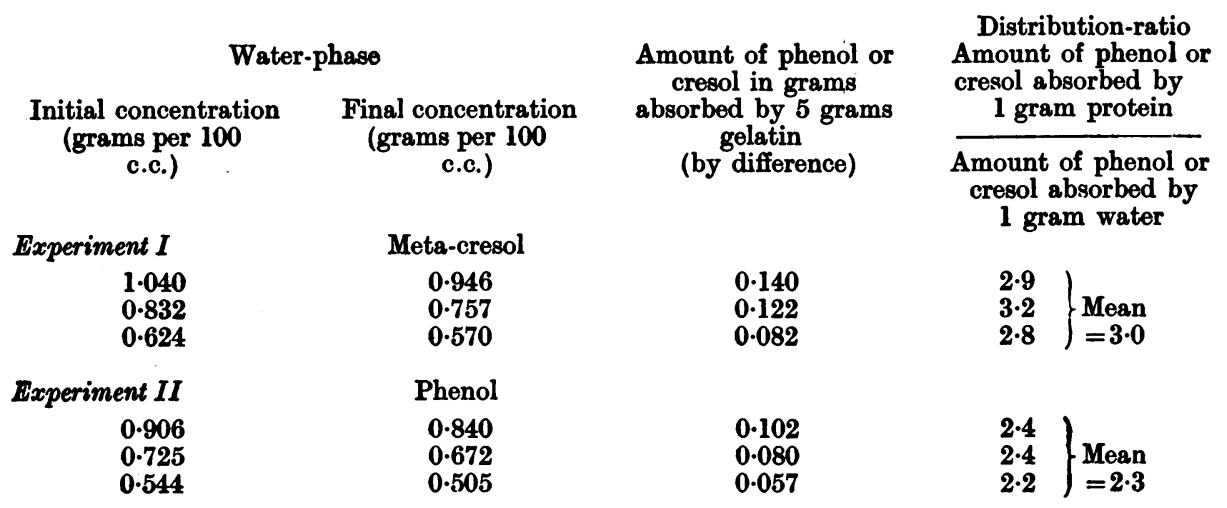


Over the small concentration range possible to work with, owing to the slight solubility of cresol in water, the distribution of meta-cresol between water and gelatin followed the partition-law, and quantitatively was very similar to that of phenol between the same solvents.

Since meta-cresol is much less soluble than phenol in water, the above results indicate that the introduction of a methyl group into the benzene nucleus of phenol decreased its solubilities in water and gelatin to approximately the same degree.

\section{(b) Egg-albumen (dialysed solution)}

A 0.7 per cent. solution of meta-cresol was sufficient to produce a turbidity in a 10 per cent. egg-albumen solution, and a 1 per cent. solution immediately produced a copious precipitate of protein, which was irreversible. A 1 per cent. solution of phenol, however, only caused a faint turbidity in an egg-albumen solution of the same strength. The introduction of a methyl group into the benzene ring of phenol therefore increased its precipitating action upon egg-albumen.

In the following table are given some equilibria with meta-cresol between water and egg-albumen.

TABLE XII.-10 c.c. $10 \cdot 2$ per cent. egg-albumen solution; 50 c.c. cresol solution

\begin{tabular}{|c|c|c|}
\hline \multicolumn{2}{|c|}{ Water-phase } & \multirow{2}{*}{$\begin{array}{c}\text { Amount of } \\
\text { meta-cresol } \\
\text { in grams } \\
\text { taken up by } \\
1 \text { gram } \\
\text { protein }\end{array}$} \\
\hline $\begin{array}{c}\text { Initial } \\
\text { concentration } \\
\text { (grams per } 100 \\
\text { c.c.) }\end{array}$ & $\begin{array}{c}\text { Final } \\
\text { concentration } \\
\text { (grams per } 100 \\
\text { c.c.) }\end{array}$ & \\
\hline $0 \cdot 188$ & $0 \cdot 180$ & 0.005 \\
\hline 0.471 & 0.445 & 0.015 \\
\hline 0.846 & 0.696 & $0 \cdot 104$ \\
\hline 0.950 & 0.822 & $0 \cdot 179$ \\
\hline
\end{tabular}

Distribution-ratio Amount of metacresol held by 1 gram protein

Over the small concentration range possible to work with, the distribution of meta-cresol between water and unprecipitated eggalbumen followed the partition-law, and the cresol was $3 \cdot 1$ times as soluble in the protein as in water.

Experiment III in Table II with phenol was carried out under the same conditions as the above experiment with cresol, and it was found that phenol was 2.9 times as soluble in egg-albumen as in water. Egg-albumen, therefore, absorbed about equal amounts of phenol and cresol from solutions of the same percentage strength, so that the solu- 
bilities of phenol in water and egg-albumen were equally decreased by the introduction of a methyl group into its benzene nucleus. Since egg-albumen was precipitated by lower concentrations of cresol than of phenol, the above results indicate that the relative precipitating power of these substances was not entirely determined by their equilibrium positions between water and the protein.

A comparison of the distribution-ratio of meta-cresol between water and egg-albumen with that of the same substance between water and gelatin indicated that the solubilities of cresol in the two proteins were equal. It was found that while egg-albumen was precipitated by dilute solutions of meta-cresol, gelatin was not even affected by saturated solutions (1.25 per cent.). As in the case of phenol, the susceptibilities of these proteins to precipitation by cresol were therefore not entirely determined by their absorptive capacities for this substance.

The precipitation of egg-albumen by cresol was accompanied by a large increase in the absorptive capacity of the protein for this substance. This increased absorption took place at a lower concentration with cresol than with phenol owing to the greater precipitating power of the former substance.

\section{VI}

\section{The Solubility of Proteins in Phenol and Meta-cresol}

Ritthausen (1872), ${ }^{6}$ and Osborne ${ }^{7}$ and his co-workers (1891-93), found that zein dissolved in warm crystallized phenol. Kjeldahl $(1896)^{8}$ showed that gliadin was also soluble in para-cresol and was precipitated from its phenol solution by many organic reagents.

Reichel (1909) ${ }^{1}$ found that when serum was warmed with anhydrous phenol a clear solution resulted which underwent no apparent change on boiling.

The high solvent powers of egg-albumen and gelatin for phenol suggested that these proteins would also be soluble in anhydrous phenols.

When egg-albumen crystals were heated with molten phenol at $45^{\circ} \mathrm{C}$. the protein gradually dissolved, and a clear solution was obtained. On dialysis or the addition of water to this solution the protein was precipitated. This was also effected by dialysing at $45^{\circ} \mathrm{C}$. Similarly heat-coagulated egg-albumen dissolved in molten phenol and was reprecipitated when the solution was diluted. Gelatin dissolved in 
phenol less readily than egg-albumen. It could be recovered in the unprecipitated state from the solution by dialysis at ordinary temperatures.

Meta-cresol also dissolved egg-albumen and gelatin at temperatures of about $40^{\circ} \mathrm{C}$. Solution was not detected at room temperatures. By dialysing these solutions at room temperatures while the egg-albumen separated as a coagulum, the gelatin was recovered in the unprecipitated condition.

The facts that egg-albumen could only be recovered from these solutions in the precipitated state, while gelatin could be recovered in an unaltered condition, corresponded with the known differences in the stability in the presence of water or dilute phenol solutions of the products of the precipitating action of the phenols upon these proteins.

When anhydrous meta-cresol was added to $1 / 2$ its volume of horseserum at ordinary temperatures the serum proteins were precipitated, but on heating to $100^{\circ} \mathrm{C}$. these were redissolved and a clear homogeneous fluid resulted. On cooling the liquid again became turbid owing to separation of the proteins. Meta-cresol rapidly dissolved Witte's peptone at $100^{\circ} \mathrm{C}$., forming a brown liquid. Solution was also found to proceed slowly at ordinary temperatures.

Although meta-cresol dissolved proteins readily, it had no solvent action, even at high temperatures, upon the amino acids, glycyl-l-tyrosin and di-alanyl-cystin. These amino-acids also differed from proteins in not being precipitated from their aqueous solutions by strong solutions of phenol.

\section{VII}

The Application of Some of these Facts to the Theory of Phenot Disinfection

\section{I.-The influence of alcohol upon the germicidal power of phenol}

Kronig and Paul (1897) ${ }^{10}$ showed that the germicidal action of phenol upon anthrax spores was decreased by the presence of alcohol, a solution of phenol in 98 per cent. alcohol possessing only a very feeble bactericidal power.

The experiments described in Section III showed that the presence of alcohol decreased the uptake of phenol by heat-coagulated albumen. The decrease was of such magnitude that the protein absorbed eight 
times as much phenol from an aqueous solution as from a solution of phenol in 50 per cent. alcohol.

The inhibiting influence of alcohol upon the bactericidal action of phenol is sufficiently explained by a decreased uptake of phenol by the spore-proteins, i.e., to a decreased amount of phenol available for disinfection.

It may be pointed out in this connection that, although the addition of acids considerably increases the germicidal action of phenol and cresol, the presence of hydrochloric acid only very slightly increased the uptake of phenol by egg-albumen. This suggests that the effect of acid upon germicidal power is only to a small extent due to an increased uptake of phenol by the bacterial proteins. It is probably due chiefly to the bactericidal action of the acids themselves.

11.-The effect of the presence of organic matter upon the germicidal action of phenol and cresol

Blyth, 11 in 1906, showed that the bactericidal action of phenol and cresol was decreased by the presence of milk, and to a lesser extent by separated milk. As the latter contains the proteins and sugar of the original milk with only a trace of fat and as lactose was found to have practically no effect upon the germicidal action of phenol, the depreciating effect of separated milk upon bactericidal action must be due to its constituent proteins. Some experiments recorded in Section I showed that casein absorbed phenol from aqueous solution. In a mixture of separated milk and phenol solution the casein therefore renders a considerable portion of the germicide unavailable for disinfection, and in this rests the explanation of the depreciating effect of separated milk upon bactericidal action.

\section{III.-The influence of temperature upon the germicidal action of phenol}

Henle (1889) ${ }^{12}$ showed that the disinfection of $B$. typhosus was more rapidly completed if the temperature of medication were raised.

H. Chick $(1908)^{13}$ quantitatively determined the influence of temperature upon the rate of disinfection of $B$. paratyphosus by phenol. It was found that the velocity of disinfection increased seven to eight fold for a rise in temperature of $10^{\circ} \mathrm{C}$.

Since it was found that the uptake of phenol by an unprecipitated protein (gelatin) proceeded very rapìdly, being complete within two minutes even at low concentrations, the influences of temperature upon 
the equilibrium positions of phenol between water and proteins and upon the velocity of disinfection can be compared. It was shown that a rise in temperature of about $15^{\circ} \mathrm{C}$. had no measurable effect upon the distribution of phenol between water and unprecipitated proteins. This suggests that the great accelerating influence of rise in temperature upon the process of disinfection is not due to an increased uptake of phenol by the bacterial proteins, but must be due to an increased velocity of a reaction between the phenol and proteins which proceeds subsequently to the absorption.

\section{IV.-The unequal germicidal powers of phenol and meta-cresol}

Several investigators have shown that the germicidal power of meta-cresol exceeds that of phenol. This is indicated in the following table, in which the number of times meta-cresol exceeds phenol in germicidal power is represented by the carbolic acid co-efficient.

\section{Organism}

$\begin{array}{lllll}\text { B. typhosus } \quad \ldots & \ldots & \ldots & \ldots\end{array}$

Staphylococcus py. aur $\quad \ldots . \cdots$

B. coli
Carbolic acid co-efficient of meta-cresol
(Pure phenol $=1 \cdot 0)$

$2 \cdot 6$

$2 \cdot 0$

$2 \cdot 1$

The experiments described in Section V showed that, although metacresol was superior to phenol in its precipitating action upon egg-albumen, there was no difference in the amounts absorbed by this protein from equal concentrations of the two substances.

The introduction of a methyl group into the benzene nucleus of phenol therefore led to an increase in both bactericidal power and proteinprecipitating power, but to no change in the uptake of the phenol by the protein. This suggests that the superiority of meta-cresol over phenol as a germicidal agent is due to the fact that cresol precipitates proteins in smaller concentrations than phenol.

\section{V.-Selective germicidal action}

The germicidal power of a substance depends upon the nature of the organism employed. This is indicated in the following table :-

\section{Organism}

B. typhosus $\quad \ldots \quad \ldots \quad \ldots . \quad \ldots \quad \ldots$

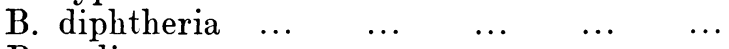

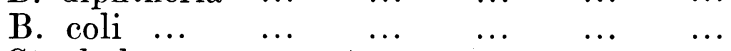

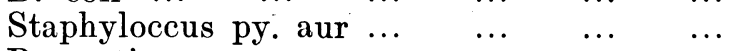

B. pestis
Concentration of phenol killing in 15 mins. under constant conditions

7 in 1,000

5 in 1,000

8 in 1,000

10 in 1,000

7 in 1,000

The cresols exhibit similar cases of selective germicidal action. 
Some experiments described in a previous section showed that proteins possessing equal absorptive capacities for a phenol were unequally susceptible to its precipitating action. This suggests that the phenomenon of selective germicidal action is determined by the phenol concentration at which the specific proteins are precipitated.

\section{Summary and Conclusion}

\section{I.-On the relations of phenol and meta-cresol to proteins}

1. Gelatin and egg-albumen absorb phenol and meta-cresol according to the partition-law.

2. When a certain phenol concentration is reached the proteins are precipitated. This is accompanied by a great increase in their absorptive capacities for phenol.

3. The precipitation of gelatin by phenol is reversible, and the absorption of phenol by this protein is also reversible throughout the whole range of phenol concentration in water. The precipitation of eggalbumen, on the other hand, is irreversible, and the precipitated protein retains permanently its high absorptive capacity for phenol.

4. Heat coagulation also increases the solvent power of egg-albumen for phenol and, except at low concentrations, influences the equilibrium of phenol between water and this protein to about the same degree as phenol precipitation.

5. Meta-cresol does not precipitate gelatin, but it precipitates egg-albumen at lower concentrations than phenol. The precipitation leads to an increase in the absorptive capacity of the protein for cresol.

6. The solubilities of phenol in gelatin and egg-albumen at $20^{\circ} \mathrm{C}$. are equal. This is also true of meta-cresol. Although this is the case, egg-albumen is precipitated by lower phenol and cresol concentrations than gelatin. The susceptibilities of the two proteins to precipitation are therefore not entirely determined by their absorptive capacities for the phenols.

7. Egg-albumen absorbs identical amounts of phenol and metacresol from equal percentage concentrations, but is precipitated by lower concentrations of cresol than of phenol. The relative precipitating power of these substances is therefore not entirely determined by their equilibrium positions between water and the protein.

8. Heat-coagulated egg-albumen and egg-globulin absorb phenol according to the partition-law. Their solvent powers for phenol are approximately equal. 
9. Casein at low concentrations absorbs phenol according to the partition-law. Above 1.8 per cent., however, with rising concentration there is an increased proportional uptake of phenol. The absorption is reversible. Casein possesses the high absorptive capacity of precipitated proteins.

10. Rise in temperature has no measurable effect upon the distribution of phenol between water and egg-albumen and gelatin; it leads, however, to a slightly decreased uptake of phenol by heatcoagulated egg-albumen.

11. Alcohol considerably decreases the uptake of phenol by heatcoagulated egg-albumen. Hydrochloric acid, on the other hand, slightly increases the uptake.

12. Egg-albumen (crystallized or heat-coagulated) and gelatin dissolve in warm anhydrous phenol and meta-cresol. When the solutions are dialysed, the albumen is irreversibly precipitated, while the gelatin can be recovered in the unaltered condition.

13. Horse-serum forms a homogeneous fluid with about twice its volume of meta-cresol at $100^{\circ} \mathrm{C}$. On cooling the serum proteins are precipitated.

14. Although meta-cresol dissolves proteins and also peptone, it does not dissolve even at high temperatures the polypeptides-glycyl-l-tyrosin and di-alanyl-cystin. These substances are also not precipitated from aqueous solution by strong phenol solutions.

\section{II.-The application of some of these facts to the theory of disinfection}

1. The depreciating effect of alcohol upon the bactericidal action of phenol is explained by a reduction in the absorptive capacities of the bacterial proteins for this substance. The action of hydrochloric acid in increasing the germicidal power of phenol, on the other hand, is only partially explained by a redistribution of phenol between water and proteins.

2. The depressing effect of separated milk upon the germicidal action of phenol is due to the absorptive capacity of the constituent casein for this substance.

3. The great increase in the germicidal power of phenol, which results from rise in temperature, is not explained by the influence of temperature upon the distribution of phenol between water and proteins.

4. The superiority of meta-cresol to phenol as a germicide appears to be due to the fact that cresol precipitates proteins in lower concen. trations than phenol. 
5. The selective action of phenol as a germicide upon different organisms seems to be associated with the observed dissimilar susceptibilities of proteins to its precipitating action.

\section{Main Conclusion}

The absorption of the phenols by bacteria is merely the initial stage in the process of disinfection.

The germicidal action which follows the absorption does not seem to be the result of a typical chemical union between the phenols and bacterial proteins, as is the case, for instance, with formaldehyde, but is apparently associated with the de-emulsification of the colloidal suspension as evidenced by the precipitation of proteins when a certain phenol concentration is attained. In the case of egg-albumen the change is irreversible, and the precipitated protein is not again dispersed on the removal of the phenol. The germicidal action of phenol thus appears to be similar in mechanism to that of heat. This interpretation of the process of disinfection by phenol may explain the fact that below certain concentrations (about 0.5 per cent.) this substance exerts but a very feeble bactericidal action, there being a disproportionate falling off in germicidal power when the phenol concentration is reduced to this point.

I desire to express my best thanks to Dr. C. J. Martin, F.R.S., for much helpful advice in the course of this work.

\section{REFERENCES}

1. Reichel, 'Zur theorie der desinfektion,' Biochem. Zeitschrift XXII, p. 149, 1909.

2. Herzog and Betzel, ' Zur theorie der desinfektion,' Hoppe-Seyler's Zeit. physiol. Chemie, LXVII, iv and v, p. 309, 1910 ; LXXIV, iii, p. 221, 1911.

3. Lloyd, Journ. Amer. Chem. Soc., p. 23, 1905.

4. Hopkins and Pinkus, Journ. Physiology, XXIII, p. 130, 1898.

5. Moore and Bigland, Bio-Chem. Journ., Vol. V, p. 32, 1910.

6. Ritthausen, Die Eiweisskorper der Getreidearten, Bonn, 1872.

7. Osborne and co-workers, 'Alcohol soluble proteins,' Amer. Chem. Journ., XIII, XIV, $\mathrm{XV}, 1891-93$.

8. Kjeldahl, 'Untersuchungen über das optische Verhalten einiger vegetabilischer Eiweiss. korper,' Beid. Cent., XXV, pp. 197-199, 1896.

9. Mathewson, 'The optical rotation of gliadin in certain organic solvents,' Journ. Amer. Chem. Soc., XXVIII, pp. 1482-1485, 1906.

10. Kronig and Paul, Zeitsch. für Hygiene, XXV, ii, p. 1, 1897.

11. Blyth, 'The standardization of disinfectants,' Journ. Soc. Chem. Ind., December 31, 1906.

12. Henle, 'Ueber Creolin und seine wirksamen Bestandtheile,' Archiv. t. Hygiene, Vol. IX, p. $188,1889$.

13. Chick, 'An investigation of the laws of dịinfection' Journ, Hygiene, Vol, VIII, No. I, January, 1908. 